\title{
ArcheoSciences
}

Revue d'archéométrie

33 (suppl.) | 2009

Mémoire du sol, espace des hommes

\section{Simulation of astronomical aspects of Middle Neolithic circular ditch systems}

Georg Zotti, Wolfgang Neubauer, Petra Schneidhofer and Ralf Totschnig

\section{(2) OpenEdition \\ 12 Journals}

\section{Electronic version}

URL: https://journals.openedition.org/archeosciences/1875

DOI: 10.4000/archeosciences. 1875

ISBN: 978-2-7535-1599-4

ISSN: 2104-3728

Publisher

Presses universitaires de Rennes

\section{Printed version}

Date of publication: 30 October 2009

Number of pages: $379-382$

ISBN: 978-2-7535-0943-6

ISSN: $1960-1360$

\section{Electronic reference}

Georg Zotti, Wolfgang Neubauer, Petra Schneidhofer and Ralf Totschnig, "Simulation of astronomical aspects of Middle Neolithic circular ditch systems", ArcheoSciences [Online], 33 (suppl.) | 2009, Online since 30 October 2011, connection on 01 February 2022. URL: http://journals.openedition.org/ archeosciences/1875; DOI: https://doi.org/10.4000/archeosciences.1875 


\title{
Simulation of astronomical aspects of Middle Neolithic circular ditch systems
}

\author{
Georg Zotтi*, Wolfgang Neubauer*, \\ Petra Schneidhofer* and Ralf Totschnig*
}

Key words: Magnetic prospection, Archaeo-astronomy, Middle Neolithic, Virtual reconstruction.

\section{INTRODUCTION}

The oldest Middle European monuments (approx. $4850 / 4750-4550 / 4500 \mathrm{BC}$ ) were presented in the Lower Austrian County Exhibition at Heldenberg in 2005 (Daim \& Neubauer, 2005). The Middle Neolithic circular ditch systems, or Kreisgrabenanlagen (KGA), are known all over Middle Europe. These wooden monuments form a first pan-European phenomenon, crossing the cultural borders defined by the archaeological material record. One third of the approx. 135 monuments known so far are found in the eastern federal states of Austria. All known Austrian KGAs have been magnetically prospected by the Team Archeo Prospections in 2003 and 2004, in preparation for the exhibition mentioned above. The acquired magnetic data were combined with aerial photographs, digital terrain models, cadastral maps etc. by means of a GIS for the subsequent combined archaeological interpretation and archiving. This digital archive, a comprehensive and comparable database existing so far only for the KGA's of Lower Austria, is now being used for the ongoing project ASTROSIM.

\section{Astronomical aspects of KGAs}

Contrary to more recent megalithic monuments like Stonehenge, the continental wooden KGAs are not preser- ved in the landscape. But as soon as the first maps were available, the KGAs became subject of archaeo-astronomical considerations. The main interest was set on the orientation of the entrances (Weber, 1986; Becker, 1996; Karlovský, 1999; Karlovský \& Pavúk, 2002). Ritual sky observations have been proposed most notably by Becker (1996) who based his analysis on magnetograms which indicated that the entrances of the Bavarian KGAs are oriented towards rising or setting points of the Sun at the solstices. According to the first investigations in 2003-2004 of selected monuments in Lower Austria, solar alignments of entrances could be verified for several KGAs with a higher degree of detail and reliability than the previous approaches. In addition, due to the availability of comparable data from the systematic archaeological prospection of a large group of monuments, a new hypothesis concerning stellar orientation of entrances has been proposed (Zotti, in Daim and Neubauer, 2005).

The new project ASTROSIM (supported by the Austrian Science Fund, FWF P21208-G19) is aiming towards an even more detailed and comprehensive scientific analysis of the archaeo-astronomical aspects of the KGAs in Middle Europe. The main objective is to verify the existing hypotheses on the astronomical aspects of the monuments by investigating solar, stellar and lunar celestial positions at phenomenological key dates in the reconstructed Middle Neolithic sky, including the horizon and atmospheric phenomena. Such studies require both an accurate survey of the

*Vienna Institute for Archaeological Science, University of Vienna, Franz Klein-Gasse 1/V, A-1190 Vienna, Austria. (georg.zotti@univie.ac.at) 
archaeological features and the local horizon, and knowledge of the astronomical processes and the solar, lunar, and stellar positions of respective periods in the past. Not every entrance was necessarily intended to be aligned towards some rising or setting point of a certain celestial object. However, the frequency distribution in a histogram of the orientations of the entrances and palisade gaps leading into the interior of the monuments shows respective peaks for some directions easily connected to astronomically significant directions (Fig. 3). Furthermore, it was already possible to propose an interpretation for a few of these detected peaks.

\section{SOLAR ORIENTATIONS}

For the directions associated with the Sun, the most obvious peaks are near azimuth $127^{\circ}$ (sunrise at Winter solstice) and south of $115^{\circ}$ (sunrise at Candlemas/All-SaintsDay), thus marking middle and start/end of a "Winter" season centered around the Winter solstice (Fig. 1). The Middle Neolithic "Summer" appears to be marked mostly with begin and end dates in only a few KGAs, while even less palisade gaps appear to point towards the direction of the summer solstice.

However, it seems evident that not only solar directions played a role in the orientations of KGAs. While our data currently do not offer a clear connection to lunar standstill risings or settings, there are two strong peaks where the sun rises or sets at "insignificant" dates of the year, and two less conspicuous peaks near the north and south, which the sun cannot reach.

\section{STELLAR ORIENTATIONS}

The short and well-known epoch of the KGAs allowed us also to investigate possible stellar orientations, and indeed, around $4700 \mathrm{BC}$, there have been two very conspicuous objects rising respectively setting at the directions of the strongest peaks in the histogram: the Pleiades star cluster (rising towards $105-108^{\circ}$ ) and the bright star Antares in Scorpius (setting near $275-279^{\circ}$ ). Moreover, the events of the rising Pleiades and setting Antares took place almost simultaneously (Fig. 2). Further investigation led to the conclusion that the
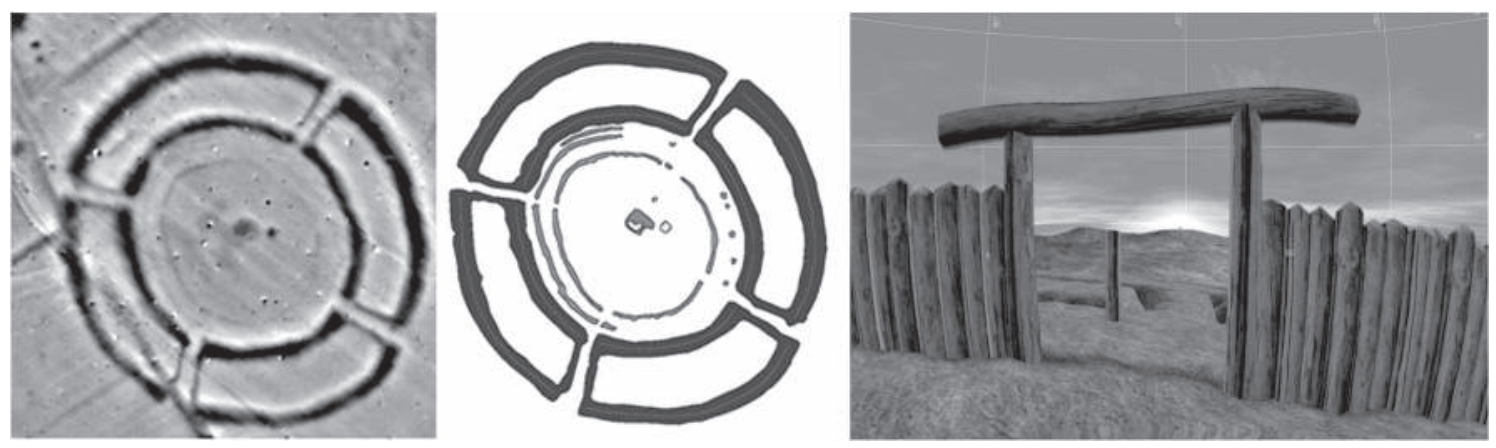

Figure 1: Kreisgrabenanlage Steinabrunn in Lower Austria: Magnetogram (left), and archaeological interpretation map (center). The right panel shows a simulated virtual view through the southeast entrance along a radial ditch pointing towards a hill where the Sun rises at "begin" (early November) and "end" (early February) of "Winter".
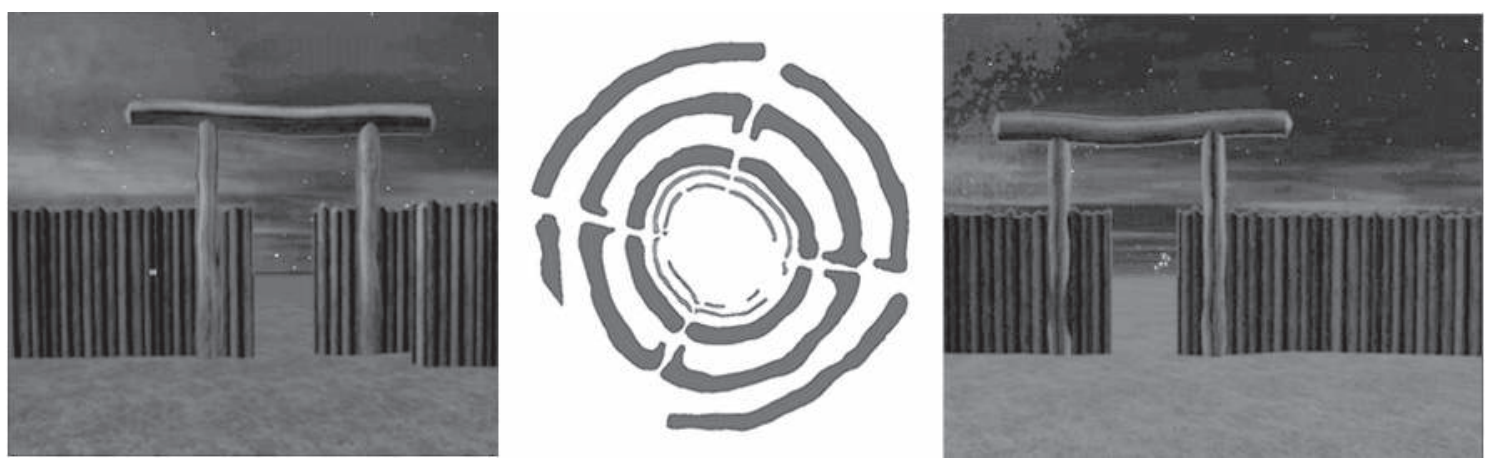

Figure 2: KGA Immendorf. In the virtual reconstruction combined with astronomical software, the Pleiades star cluster rises as seen through the southeast entrance (right), while Antares sets as seen through the north-west entrance (left). 


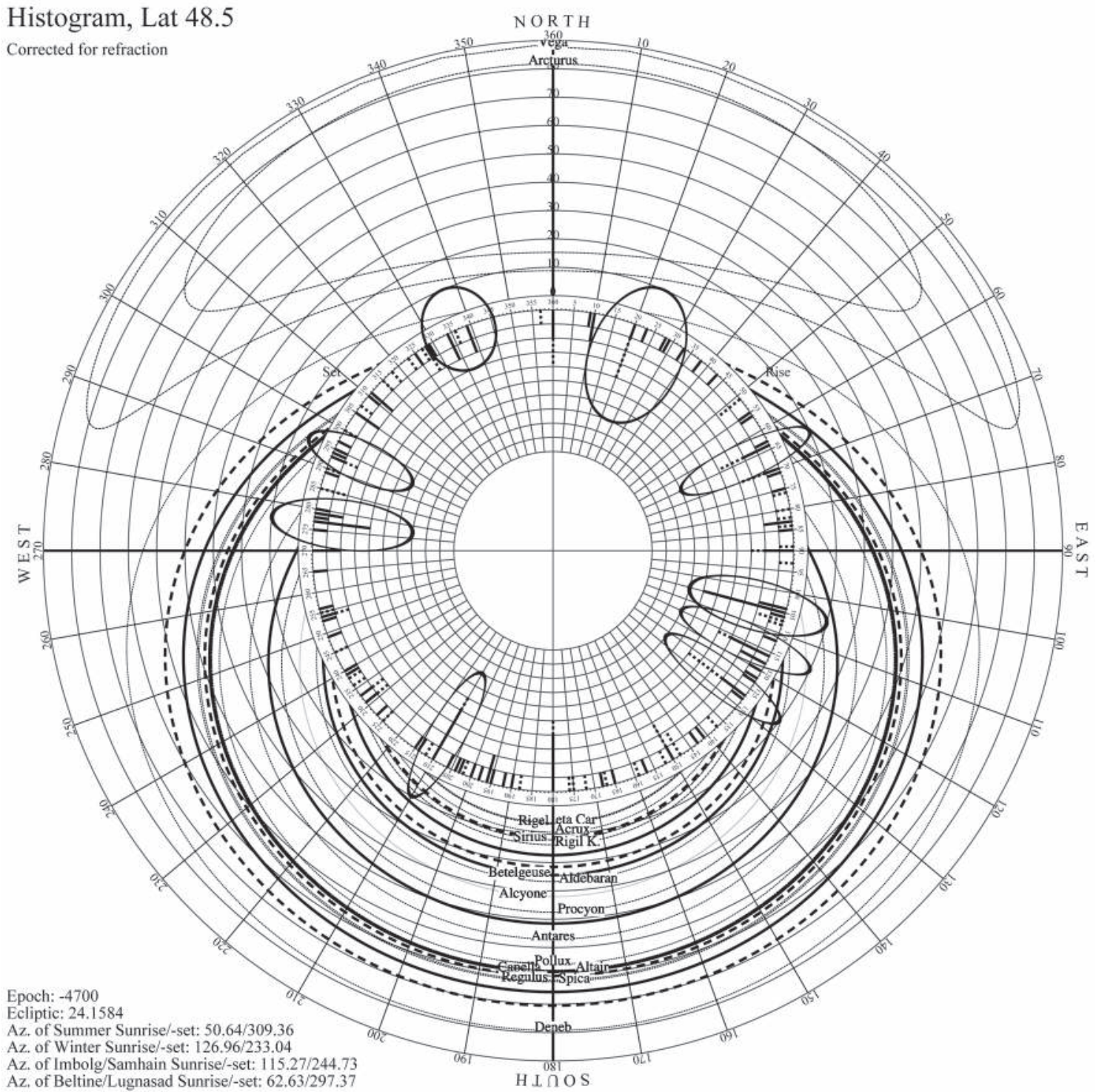

Figure 3: A histogram view of data of 27 KGAs. In the central area, radial lines inward indicate the number of KGAs with an entrance or palisade gap pointing towards the respective direction, if viewed from the KGA center. Full lines indicate directions of radial ditches or entrances, dashed lines indicate less conclusive gaps in the palisades. The ellipses indicate frequency peaks identified so far.

Pleiades' heliacal rising at that time took place just after spring equinox. The Pleiades have been observed by many cultures worldwide in connection with seasons and agriculture, although a star cluster like the Pleiades, which consists of dim stars, cannot be observed very low on the horizon. The current lack of horizon data however impedes primary research on the question whether the Pleiades may have risen visibly behind a raised landscape horizon (e.g. chain of hills), and also on the possible connection of door orientations in the northern and southern horizon ranges with other stars.

\section{VIRTUAL RECONSTRUCTION AND ASTRONOMICAL SIMULATION}

In this project we intend to build virtual reconstruction models of all monuments in combination with the DTMs. These models will be used with a simulation of the middle Neolithic sky to visualise and to verify the proposed hypotheses in the virtual world. The solid archaeo-astronomical analysis of the existing database is expected to be used for an enhanced functional interpretation of the KGAs. In addi- 
tion, an interpretation of the potential use of systematic sky observations aided by the found entrance orientation can help to understand aspects of practical astronomical activities and knowledge of the sites' users.

\section{References}

BeCKER, H., 1996. Kultplätze, Sonnentempel und Kalenderbauten aus dem 5. Jahrtausend vor Chr. - Die mittelneolithischen Kreisgrabenanlage in Niederbayern, in: Archäologische Prospektion. Luftbildarchäologie und Geophysik, Arbeitshefte des Bayerischen Landesamtes für Denkmalpflege 59, 1996, $101 \mathrm{ff}$.

Daim, F. and Neubauer W., 2005. Zeitreise Heldenberg. Geheimnisvolle Kreisgräben. Niederösterreichische Landesausstellung 2005. Katalog des NÖ Landesmuseums, 459, 2005.
KarLovsKÝ, V., 1999. Rondel v Bucanoch ako mozné slnecné a mesacné oberservatórium (Rondel in Bucany possibly served as a solar and lunar observatory). Materialia Archaeologica Slovaca, Communicationes 2, $111 \mathrm{ff}$.

Weber, Z., 1986. Astronomische Orientierung des Rondells von Těšetice-Kyjovice, Bez. Znojmo. Internationales Symposium über die Lengyel-Kultur, Nitra-Wien, $313 \mathrm{ff}$.

KarlovskÝ, V. and Pavúk, J., 2002. Astronomická orientácia rondelov lengyelskej kultúry. In: I. Cheben, I. Kuzma (dir.). Otázky neolitu a eneolitu našich krajín - 2001, Archaeologica Slovaca Monographiae - Communicationes 4, 113-127.

Karlovskŕ, V., 1999. Rondel v Bucanoch ako mozné slnecné a mesacné oberservatórium (Rondel in Bucany possibly served as a solar and lunar observatory). In I. Kuzma (dir.). Otázky neolitu a eneolitu našich kraijín - 1998, Materialia Archaeologica Slovaca - Communicationes 2, $111 \mathrm{ff}$. 